\begin{tabular}{|c|c|c|c|}
\hline 2 UNT & JASA & $\begin{array}{r}\text { Journal of } \\
\text { English Language Teaching } \\
\text { Innovations and Materials }\end{array}$ & \\
\hline $\begin{array}{l}\text { Article received } \\
\text { Article accepted } \\
\text { Published }\end{array}$ & $\begin{array}{l}: 9^{\text {th }} \text { June } 2019 \\
: 2^{\text {th }} \text { March } 2020 \\
: 16^{\text {th }} \text { April } 2020\end{array}$ & (JELTIM) & $\begin{array}{c}\text { Vol. 2(1) } \\
\text { April } \\
2020\end{array}$ \\
\hline
\end{tabular}

\title{
Global materials versus local materials for students' reading comprehension: a library research
}

\author{
Heri Kurniawan \\ Master's Study Program of English Language Education, Universitas Tanjungpura, \\ Pontianak, Kalimantan Barat, Indonesia \\ herikurniawan344@yahoo.com
}

DOI: http://dx.doi.org/10.26418/jeltim.v2i1.32831

\begin{abstract}
This study scientifically aimed to investigate whether or not local materials influences reading comprehension towards students in general instructional settings, compared to global materials. The researcher conducted the study by collecting 20 empirical research articles from 2009 till 2018 through computer searches from the database and through book readings, related to global and local materials and experimental studies for investigating the effectiveness between the global and the local materials towards learner's reading comprehension. As soon as the researcher gathered the articles, the articles were then analyzed and synthesized into data results and discussion related to the theories. The researcher also consulted data result and consultation with the experts of the English Language Teaching Materials. The result had synthetically shown that the local materials, integrated local culture content inside were more active compared by the global materials for reading comprehension because of students' background knowledge of their local cultural familiarity in the target language materials. It also emphasized the strong influence of the usage of it for students' reading comprehension improvement.
\end{abstract}

Keywords: English Learning Material, Global Material, Local Materials, and Reading Comprehension

How to cite this paper: Kurniawan, H. (2020). Global materials versus local materials for students' reading comprehension: a library research. Journal of English Language Teaching Innovations and Materials (JELTIM), 2(1), 49-62. DOI: http://dx.doi.org/10.26418/jeltim.v2i1.32831

Journal of English Language Teaching Innovations and Materials (JELTIM), 2(1), 49-62 Copyright (C) 2020 by JELTIM, e-ISSN 2657-1617 
As it is known, teaching and learning English need process, then a teacher teaches and instructs, and students will learn what they see, hear and, do from the teacher. Such everyday activities take place in an instruction matter. English is also unquestionably taught in every kind of educational institution. Teaching and learning English influence almost 2 billion people who teach and learn the global language (Graddol cited in McDonough et al., 2013). Then they can communicate with each other in schools, universities and, independent institutions such as a private course where children and adults intentionally learn English for global communication needs.

Since the English teaching and learning have been expanding, English teachers get involved in English teaching aspect areas. Teachers may get engaged in teaching English as a Foreign Language (EFL) for outside English speaking regions, English as a Second Language (ESL) for inside English speaking regions to non-native learners, English for Young Learners (EYL) for an additional language to very young to young learners, English for Specific Purposes (ESP) for specific occupational purposes such as English for medicine and business, English for Academic Purposes (EAP) for those who wish to study at institutes of higher education as well as Content and Language Integrated Learning (CLIL) for cross-curricular programs (McDonough et al., 2013).

As the teaching and learning occur, teachers will practically deliver lessons of English to students with varieties of instruction activities such as methods and techniques. With the hope of using those, the lessons should be easily matched with students' learning styles and effectively transferred among the students so that the students have skills to practice the language. Methods with teachers' instruction expectation suits on what students need to learn and are the suitable teaching plan to match the learning style, the students apply for communication (Brown, 1995). Therefore, teachers need to recognize which methods affect students' learning.

Besides, teaching and learning process need to be equipped not only through methods and techniques but also something visual, well-known materials (Patel \& Jain, 2008). They have an essential aspect (approach, methods, and techniques do too) of language teaching and learning (Garton \& Graves, 2014). Related to the definition stated previously, Hutchinson \& Water (1987) added that the materials involve one of the most characteristic features (among approach, methods, and techniques) applied in instruction activities. Based on the definitions stated by the experts, they play a vital role in enabling teachers to demonstrate and teach about how the language communicates.

The role of materials themselves instructively gives a considerable contribution to teachers and learners as they expect how easily they can see how the language communicates through them. Furthermore, there are any resources

Journal of English Language Teaching Innovations and Materials (JELTIM), 2(1), 49-62 Copyright ( 2020 by JELTIM, e-ISSN 2657-1617 
of teaching and learning processes, including a textbook, workbook, written paragraph, and even a CD ROM in coursebooks as the primary teaching and learning material (Garton \& Graves, 2014). For teachers with less teaching experience, the coursebooks supply the availability of rich instruction manual, which guide the teachers for practical activities. The coursebooks are systematically made by including in all forms (written text, audio as well as video) and language learning tasks in which they cover all lessons in English internationally. Then the coursebooks become global coursebooks because they are officially published and distributed around the world. Moreover, they are usable for English teaching and learning towards both teachers and students around the world. The global coursebooks seem to be published in all places and give a fundamental role for English teaching and learning process around the globe (Garton \& Graves, 2014).

According to Tomlinson et al. (2001), global coursebooks for general English aim at the dual markets of language courses in English-speaking countries and English as a foreign language. The coursebooks are those from the real English communication of the native speakers, living in both British English and American English countries, in the content of the coursebooks (Tomlinson, 2011). Then the use of the coursebooks is referred for both inside Englishspeaking regions to non-native learners and outside English-speaking areas. Furthermore, the coursebooks provide non-written and spoken texts for the teaching-learning processes such as newspapers, magazines, shopping, advertisements, manuals, invitation cards, brochure, product wrappings, menus, train schedules, e-mails, announcements, manuals as well as poems (Brian Tomlinson, 2011). Then the contents of the coursebooks, used in the teaching and learning process, enable learners to increase their communicative competence.

Beneficially, the coursebooks can enhance the learners to view how real English communicates through its reading texts. The coursebooks also facilitate the learners to acquire reading comprehension. A study on the effect of the global materials on Pakistani ESL learners showed that that the use of global materials enthusiastically made their participants interested and significantly helped them to enhance their reading comprehension using reading global materials (Aftab \& Salahuddin, 2015).

Among the effects of the global coursebooks as the English instructional materials, there had been; surprisingly, revealed that global coursebooks probably had been sprung by less apparent issues. There were linguistic and cultural background problems faced in reading comprehension. As most learners linguistically faced were that the coursebooks are challenging for the learners since the reading texts in the coursebook contain difficult language elements like non-specific vocabulary items and complex language structures leading the students' less comprehensive. Culturally, the contents of the coursebooks, which

Journal of English Language Teaching Innovations and Materials (JELTIM), 2(1), 49-62 Copyright ( 2020 by JELTIM, e-ISSN 2657-1617 
cover cultural international or global topics made different and unfamiliar from the learners' local cultural background topics, causing the learners confusion and misunderstanding towards their reading comprehension. The global coursebooks seem to show disaffection of the teacher's and learners' needs (Masuhara et al. cited in Garton \& Graves, 2014). Also, Tomlinson et al. cited in Garton \& Graves (2014) revealed that the coursebooks they reviewed did not cover learners' needs to local contexts.

On the other hand, another alternative for English materials or coursebooks for reading comprehension which is called Local materials or Local coursebooks. They consist of cultural texts in the materials, including both national and local English language materials based on the curriculum demand and their national learners' needs (Mishan \& Timmis, 2015). Based on a study of using local materials had shown that local culture-based materials facilitate learners' English learning the content since they are common in the topics and the previous background knowledge to communicate the target language $(\mathrm{Fu}$, 2018). Then, using the local materials provides a significant contribution to the educational practitioners; they are both teachers and learners in this instruction context, to acquire the language communication since it presents English lesson, combined with national and local topics as their background knowledge. Besides, the local culture-based materials also enhance learners' sufficient reading comprehension because the students have cultural background knowledge, which helps them understand the content in reading materials, they read as one of the substantial useful contributions to teaching reading comprehension of a reading text lies in the use of local culture materials (Royani cited in $\mathrm{Fu}, 2018$ ).

This research, therefore, purposefully provides practical information towards the Educational practitioners, especially both researchers and English teachers, about comparing the effectiveness of both global and local materials used for reading comprehension in general classroom settings.

\section{METHOD}

This research involved library-based research. It reviewed some studies or literature conveying the definition of English learning materials, global materials, local materials, and presenting the effectiveness of the local materials compared by the global ones for reading comprehension in general classroom settings of non-English-speaking countries. In collectin data, there were two systematical techniques conducted. The researcher primarily gathered both 20 empirical research articles from 2001 till 2018 through computer searches from the database and book readings. They consist of two local, eight international journal articles as well as ten global book readings. They were then analyzed and synthesized into a data result related to theories. Finally, the researcher consulted the data result and discussion with the experts of English Language Teaching.

Journal of English Language Teaching Innovations and Materials (JELTIM), 2(1), 49-62 Copyright ( 2020 by JELTIM, e-ISSN 2657-1617 


\section{FINDINGS}

The finding of the empirical research articles analyzed is organized into four concise topics. They define English learning materials, global materials, local materials, and presenting the effectiveness of the local materials compared by the global ones for reading comprehension.

\section{English Learning Materials}

Apart from implementing the method for the effective English teaching and learning process, teachers, in his/her teaching implementation in the classroom, apply some teaching things for the effective teaching and learning process. Teaching and learning process needs to be something for effective teaching and learning process (Patel \& Jain, 2008). It means that teachers should provide something which assists his and her teaching towards their students. Besides, something which can be instruction assistance is called materials (Patel \& Jain, 2008). The materials can also be models for teaching and learning a language (Syamsuyurnita \& Nasution, 2017). Then teachers instructively should use the material to facilitate their students not only to view but also to learn how to apply communication of a language in the materials. Generally, the materials have an essential aspect (approach, methods, and techniques do too) of teaching and learning the language. Related to the definition stated previously, the materials are ones of the most characteristic features (among approach, methods, and techniques) applied in instruction activities (Hutchinson \& Water, 1987). Based on the definitions stated by the experts, it plays a vital role for teachers to demonstrate and teach about how English communicates.

The materials are also explicitly defined as any forms (could be probably a textbook, workbook, cassette, a CD-ROM, and paragraph on a board) to illustrate and elaborate the language (Tomlinson, 2011). Meanwhile, they, with more specific explanation, deals with instruction, experiential, elicitation, or exploratory in which they provide supplement towards the teacher's guidance and provide the learners about how to use the language independently (Richards, 2001 \& Tomlinson, 2003). They can assist learners in having independent learning since they provide the explanation, instructions and tasks of a language item (Nisa, 2019). Then, they refer to anything ready, which are used as learning assistance for explaining how the English language effectively is learned by the learners to communicate. Besides, they are designed into any tools which enable teachers to present any kinds of lessons to students about the way the language is orally spoken and well-written towards them.

Furthermore, there are many resources for teaching and learning processes, including a textbook, workbook, written paragraphs, even a CD ROM in a coursebook as the primary teaching and learning materials (Richards cited in Garton \& Graves, 2014). The most implemented and useful instructive materials for English teaching and learning process comes from English

Journal of English Language Teaching Innovations and Materials (JELTIM), 2(1), 49-62

Copyright ( 2020 by JELTIM, e-ISSN 2657-1617 
coursebooks (Mishan \& Timmis, 2015). Therefore, the coursebooks provide a beneficially significant application of the instruction.

\section{The Definition of Global Materials}

The coursebooks, as explained before, provide both learning materials for students and teaching a guide to help teachers plan their instruction process when they are in the classroom. Garton \& Graves (2014) also added those coursebooks which include teaching and learning materials (written text, learning tasks, audio as well as video) to facilitate the learning of a language for teachers and students all over the world is called global coursebooks. Besides, the reason the coursebooks is called the global ones is that they are officially published and distributed around the globe (Garton \& Graves, 2014). Teachers and students use the material as English learning resources (Tomlinson, 2011). The global coursebooks also become published in all places and give a fundamental role for English teaching and learning around the world (Garton \& Graves, 2014). Then, the coursebooks are useful for both teachers and students around the world to do the teaching and learning process.

The materials are from several sources such as storybook, newspaper, magazine, short video, song, picture, and any other materials (Oura cited in Kusumawardani et al., 2018). Using global materials are also useful to encourage students for language learning (Tomlinson, 2014). Then the coursebooks include any kinds of things such as derived from the internet, book, E-book, journal, newspapers, and others, influencing language instructions.

Furthermore, the global coursebooks' usage provide several coursebooks' advantages for TESOL and TEFL, based on the interview of Graduate TESOL Program students' global coursebooks preference conducted by Garton \& Graves (2014) that there are advantages such as providing structure lessons and to a course, spending less time for teachers for materials collection, giving a sense of security since teachers can predict the lessons they will teach, promoting selfindependent-learning for learners, providing reliability of experts and wellknown publishing, giving a sense of professionalism for providing both elaborated explanation and exercise of language items, and offering different perspectives as it focuses on different cultures and different places.

\section{The Definition of Local Materials}

Since they are called the worldwide instructive materials, another alternative for the coursebooks which can be an English teaching and learning materials and English materials for a national education's requirement where they exist, well-known local materials or local coursebooks. McDonough et al.

Journal of English Language Teaching Innovations and Materials (JELTIM), 2(1), 49-62

Copyright ( 2020 by JELTIM, e-ISSN 2657-1617 
(2013) also defined that local materials or local ones as the materials, including English lessons in which their national learning goals require lessons.

The coursebooks also cover both national and local English language materials, based on the curriculum demand and its national learners' needs (Mishan \& Timmis, 2015). Then, the teachers and students use the coursebooks as the materials of instructional matter in their nation. Barrios and Debat cited in Garton \& Graves (2014) explained several aspects, available in the local materials for the instruction effectiveness such as contextualization in the coursebooks, referring to the learner's real-life environment, linguistic contrast on the learners' self-reflection of form, the meaning, and the usage of the target language linguistics lesson through contrastivity, intercultural reflection between home and target cultures in the materials for target language culture knowledge, and learning facilitation with the involvement of the L1 in the coursebook for encouraging learner's autonomy.

According to Majthoob cited in Garton \& Graves (2014), the coursebooks enable learners, learning English, to meet their needs in a specific context (curriculum demand and learners' need). The local materials, related to the material content, locate English language lessons within familiar cultural reference points such as its concrete notion, national events, landmarks, celebrities, abstract ones, values, ambitions, family relationships, etc (Mishan \& Timmis, 2015). Barrios and Debat cited in Garton \& Graves (2014) also stated that the local coursebooks are locally designed in a specific country or region, related to learners' cultural background and national curriculum as the exam target preparation and communication. Then, students are easily able to acquire language proficiency because the local coursebooks beneficially give them a sense of familiarity through cultural topics, discussed.

Specifically, Ningtyas et al. (2016) argued the local materials involve local culture reading materials, which give considerable effectiveness towards the learners' learning reading process. They should have an inclusion of learners' cultural topics to enable them to get motivated and engaged for the learners' reading English comprehension (Grabe and Stoller cited in Murcia (2001). Therefore, the local coursebooks become a primary material because they provide English lessons and the local context, including curriculum demands, students' needs and, local culture to facilitate the teaching and learning reading comprehension process.

\section{Global Versus Local Material for Student's Reading Comprehension}

The analysis of the articles revealed surprising findings between the global coursebook and the local one for the students' reading comprehension. A study of forty-four Turkish young adult students towards their reading comprehension by using a global reading text or original text with activities (OWA) and the

Journal of English Language Teaching Innovations and Materials (JELTIM), 2(1), 49-62

Copyright ( 2020 by JELTIM, e-ISSN 2657-1617 
global or original one with no activities (ONA) that there were quite similar about 64.55 to 60.45 of mean scores between OWA and ONA (Erten \& Raz1, 2009). The same effect of using global reading texts also shown on a study result towards sixty-20-to-24-aged- participants for the use of OWA and ONA of their reading comprehension that the mean score indicated the similar static progress (about 61.06 to 55.35 of mean score) achieved by the participants in their reading comprehension (Gürkan, 2012). Besides, the reason for less-improvement by using the global materials for learners' reading comprehension is that there were unsuitable or uncommon-written-text-themes for learners in a particular country where they live (Melliti, 2013). Therefore, the students found difficulty in comprehending the texts overall because they provide different topics outside.

On the other hand, local materials effectively enable learners to talk and write about their own experiences, concerns, and culture through English because the materials provide local content input in English learning materials (Garton \& Graves, 2014). Fu (2018) also explained that materials which include both local culture topics (any form of cultural familiarity such as story texts) in language teaching and language learning are well-known local cultural-based materials for language instructions. Fu (2018: 59) illustrated that the use of local culture texts had resulted from learning motivation since they were familiar with their background culture knowledge in the target language text. Then using the local-culture-based materials give significant advantages for the teaching and learning reading comprehension, based on the finding.

Khan (2014) conducted a survey study to investigate teachers' perceptions of the significance of culture in (English Foreign Language) EFL and ESL(English Second Language) Learning materials in Jeddah and different parts of the world, especially the middle east and India. The local cultural background knowledge is in the target. The survey questioned the teachers' opinions about the effectiveness of the local materials towards their learners' learning improvement. The finding had revealed that most each aspect of the questionnaire, expressed by the respondents, provided the positive perspectives by the local materials in which both the inclusion of the local culture in the texts were able to enhance teaching and learning experiences more significant.

Furthermore, Mahabadi (2012) proved the effects of local materials on 30 male and female Iranian learners' comprehension in a French foreign language context. The finding revealed that there was 0.001 of Sig score (2-tailed) less than 0.05 of probability in which the rating means that the students were capable of providing accurate answers on questions in Pizaar's story of local materials for their comprehension. Local-culture-based-materials were suitable learning ones for learners because they provide familiar characters setting of the story in the materials, which resulted from the more in-depth understanding of the students (Mahabadi, 2013). Therefore, the finding presented that the students performed their comprehension better by reading local materials.

Journal of English Language Teaching Innovations and Materials (JELTIM), 2(1), 49-62

Copyright @ 2020 by JELTIM, e-ISSN 2657-1617 
The issue of integrating local culture content for reading comprehension also caught the attention of Turkish researchers. Erten \& Raz1 (2009) investigated the effectiveness between using global materials or original reading texts and local-culture-based materials or adjusted reading text in reading activities towards 44 advanced-level students of English at a state university in Turkey. The finding revealed that there was a significant effect of the local material, obtained from the cross-comparisons between the group of students, using the local materials outperformed $(\mathrm{M}=69.91)$ and another group of ones with global materials $(\mathrm{M}=60.45)$ of the mean score. The finding of the post-test confirmed that the students, given treatments by the local culture content, had a more significant effect than the ones by the global ones since the materials provided the background knowledge and cultural familiarity on the students' reading comprehension.

To stress out the effectiveness of localized materials for reading comprehension, another Turkish researcher, Gürkan, (2012) investigated whether or not cultural familiarity based texts in reading activities influence the target language reading comprehension towards 60 junior Turkish EFL university students. The research revealed a similar improvement result as the previous one that the participants who read the local-culture short story with reading activities outscored the other groups with the global and outperformed them by achieving the highest mean scores gained according to the results of post-test. A study conducted by Ningtyas et al. (2016) also showed that using local-culture-based materials gave a positive impact on improving reading comprehension because the familiarity with the reading material enhanced students' interest and active participation during learning. Based on the finding, it indicated that the students who read the original story with or without reading activities scored lower than their counterparts who do on the local culture version of the story. Therefore, the readers who read the local texts avoided from unfamiliar names and culturally distant contextual clues that led to worse comprehension gains.

\section{DISCUSSION}

As previously stated on the finding that English learning materials which are also called English learning coursebooks, including any assisted aided (including a textbook, workbook, written paragraphs, even a CD ROM) in facilitating learners to learn English. The materials then play a vital role in language instruction between teachers and learners as they easily could observe the way the language communicates through them. Therefore, the coursebooks provided a beneficially significant application of the instruction.

Explicitly, they supplied the availability of rich manual instruction to guide the teachers or the teachers with less teaching experience and gave students a sense of independent learning for useful instructional activities, based

Journal of English Language Teaching Innovations and Materials (JELTIM), 2(1), 49-62

Copyright ( 2020 by JELTIM, e-ISSN 2657-1617 
on the explanation stated by Richards (2001). Therefore, the coursebooks presented a map, dealing with the content of lessons and tasks to learn independently

Besides, the coursebooks had two types. They comprise the global coursebooks and the local ones with different features, as explained on the discussion before (Garton \& Graves, 2014), (Brian Tomlinson, 2014) (McDonough et al.., 2013; Mishan \& Timmis, 2015; Murcia, 2001; and Ningtyas et al.., 2016).

The global coursebooks were usable for English teaching and learning towards both teachers and students around the world they functionally provided any instruction activities in a printed book, advantages for Graduate TESOL Program students and internationally became issued to teachers and learners around the world. Therefore, it had been globally spread out and playing a crucial role in English language teaching and learning, with many advantages of the instruction activities for both teachers and students inside English speaking regions to non-native learners and outside English speaking regions.

On the other hand, the local coursebooks which are functionally characterized not only as a teaching and learning materials but also as the materials with a national education's requirement were used for English teaching and learning instructions in a country where it belongs. The local materials or local coursebooks in a specific country or region promoted a positive impact on the teaching and learning process towards educators and educatees from the finding illustrated aforementioned.

Despite the advantages of the global coursebooks in the instructional process, the coursebooks, surprisingly, had revealed that they seem to show dissatisfaction with the teacher's and learners' needs. Such dissatisfaction of such educational practitioners also resulted in a less significant impact on learners' learning process at reading comprehension, based on (Erten \& Raz1, 2009; Gürkan, 2012).

However, the local coursebooks with both local culture topics and language learning in story texts provided suitable materials that match the specific students' needs and encourage their learning motivation in reading comprehension. Therefore, the inclusion of local culture topics and documents in the instructive materials can enhance the learners' learning process because of familiarity like providing students' background culture knowledge in the target language text.

Seeing the recent studies can be assumed that local materials avoid missing a chance to promote positive attitudes (the way to communicate with cultural elements) so that they were beneficial to assist the practitioners to improve the instructional matters significantly. Moreover, the local culture-based materials which provide familiar characters setting of the story in the texts made the students outperformed their reading comprehension. The reasons were that students have background knowledge of the content and were able to have more focus on linguistics and generic structure of the text or passage to read.

Journal of English Language Teaching Innovations and Materials (JELTIM), 2(1), 49-62

Copyright ( 2020 by JELTIM, e-ISSN 2657-1617 
Based on the discussion presented and explained above, the researcher indicated that integrating local culture content is more effective compared with the global materials for students' reading comprehension because of their cultural familiarity on the target language materials.

\section{CONCLUSION}

The discussion can infer that English learning materials involve as any forms (probably a textbook, workbook, cassette, a CD-ROM, and paragraph on a board about) instruction, experiential, elicitation, or exploratory for maximizing language learning

The materials also play a vital part in the instruction process and give an abundant contribution to active language learning. The materials role provide benefits for both teachers and learners. The materials also assist learners in having a sense of independent education for learners. They give the learners space and time to either learn in the classroom or the outside. They advantageously guide the teachers through the manual instruction or lesson teaching plans provided. Since they offer a positive contribution to the instructional process towards teachers and learners, the publication of the material is internationally spread worldwide. They become global coursebooks for the availability of English language learning materials and the prevention of illiteracy in every angle areas of the world.

However, the materials or the global coursebooks arouse a bewildering learning process since the global coursebooks were found no match on the teacher's and learners' needs, leading dissatisfaction of the educational practitioners and less impact of the learners' learning process in reading comprehension. The local ones bring a new paradigm of such language learning aids in which they open learners' thought of learning English only to extend the regional aspects. It means the inclusion of local materials enhance learners' language acquisition since they involve learners' life experience, concern, and local culture with English. Related to the results of the studies, the inclusion of the local-culture-based stories in the reading texts has a significant effect on students' reading comprehension improvement.

The inclusion of the local culture in the texts provides better teaching and learning experiences. Local-culture-based-materials provide familiarity on characters setting, making the reading activities more understood towards the students. Therefore comparing the global materials and the local one on contents showed that the local ones were more significant because of the background knowledge and cultural familiarity provided on reading comprehension. Finally, the familiarity in the reading materials enhances students' interest and active participation during learning and lead them to an extra focus on linguistics and

Journal of English Language Teaching Innovations and Materials (JELTIM), 2(1), 49-62 Copyright ( 2020 by JELTIM, e-ISSN 2657-1617 
generic structure of the text or passage while they were doing reading activities. Teachers, hopefully, and highly recommended, use the local materials to increase students' reading comprehension. Also, this paper should be able to contribute to future research on similar topics towards other aspects of English proficiency such as listening, speaking, and writing skills.

\section{REFERENCES}

Aftab, A., \& Salahuddin, A. (2015). Authentic Texts and Pakistani Learners' ESL Reading Comprehension Skills: A Mixed-Method Study. Language Education in Asia, 6(2),

122-134. http://dx.doi.org/10.5746/LEiA/15/V6/I2/A4/Aftab_Salahuddin.

Brown, J. D. (1995). Elements of Language Curriculum.pdf. USA: Heinle \& Heinle Publishers.

Erten, İ. H., \& Raz1, S. (2009). The Effects of Cultural Familiarity on Reading Comprehension The effects of cultural familiarity on reading comprehension. 21(1), 60-77. Retrieved

from https://www.researchgate.net/publication/233823478.

Fu, W. (2018). Read from Local to Global: A Culture-based Reading Material. Advances in Social Sciences Research Journal, 5(2). https://doi.org/10.14738/assrj.52.4173.

Garton, Sue., \& Graves, K. (2014). International Perspectives on English Language Teaching. New York: Palgrave Macmillan.

Gürkan, S. (2012). The Effects of Cultural Familiarity and Reading Activities on L2 Reading Comprehension. 55, 1196-1206. https://doi.org/10.1016/j.sbspro.2012.09.615.

Hutchinson, T., \& Water, Al. (1987). English for Specific Purpose A learning-centred approach. Great Britain: Cambridge University Press.

Khan, I. A. (2014). Teachers' Perceptions of the Significance of Local Culture in Foreign Language Learning. Journal of English Language and Literature, 1(3), 65. https://doi.org/10.17722/jell.v1i3.41.

Kusumawardani, R., Santosa, R., \& Roschsantiningsih, D. (2018). Explore the Use of Authentic Materials to Teach Reading for Junior High School. International Journal of Multicultural and Multireligious Understanding, 5(4), 298. https://doi.org/10.18415/ijmmu.v5i4.323 
Mahabadi, S. (2013). The role of localized materials in learning of FFL students. 4(5), 65-74. https://doi.org/10.5897/JLC12.031.

McDonough, J., Shaw, C., \& Masuhara, H. (2013). Material and Method in ELT A Techer's Guide Third Edition. West Sussex: A John Wiley \& Sons, Ltd, Publication.

Melliti, M. (2013). Global Content in Global Coursebooks: The Way Issues of Inappropriacy, Inclusivity, and Connectedness Are Treated in Headway Intermediate. https://doi.org/10.1177/2158244013507265.

Mishan, F., \& Timmis, I. (2015). Materials Development for TESOL. Edinburgh: Edinburgh University Pres Ltd.

Murcia, M. C. (2001). Teaching English as a Second or Foreign Language, Third Edition. the United States of America: Heinle \& Heinle, a division of Thomson Learning, Inc.

Ningtyas, U. K., Diem, C. D., \& Vianty, M. (2016). Functioning local culture in EFL readings. Proceedings of the 2nd SULE - IC 2016, 1249-1258.

Nisa, P. P. D. (2019). Application of mandarin language module for improving language speaking skills. Journal of Applied Studies in Language, 3(2), 178-186. Retrieved from http://ojs.pnb.ac.id/index.php/JASL

Patel, M. \& Jain, P. M. (2008). English Language Teaching (Methods, Tools $\mathcal{E}$ Tchniques). Jaipur: Sunrise Publishers \& Distributors.

Richards, J.C. (2001). Curriculum Development in Language Teaching. Cambridge: Cambridge University Press

Syamsuyurnita, S. \& Nasution, D. K. (2017). Development of Indonesian language book using Glasser model. Journal of Applied Studies in Language, 1(1), 15-22. Retrieved from http://ojs.pnb.ac.id/index.php/JASL

Tomlinson, B. (2014). Developing materials for language teaching: Chapters from the first edition. London: Bloomsbury Publishing Plc.

Tomlinson, B. (2011). Materials Development in Language Teaching Second Edition. the United Kingdom: Cambridge University Press. Retrieved from www.cambridge.org/9780521157049 
Tomlinson, Brian. (2003). Developing Material for Language Teaching. London: Crownwell Press.

Tomlinson, B., Dat, B., Masuhara, H., \& Rubdy, R. (2001). Survey review. EFL courses for adults. ELT Journal, 55(1), 80-101. https://doi.org/10.1093/eltj/55.1.80.

\section{Authors' Brief CV}

Heri Kurniawan is completing his studying in Master's Study Program of English Language Education of Universitas Tanjungpura, Pontianak, Indonesia. He also teaches as English teacher in the Integrated Islamic Junior High School (SMPIT) AL MUMTAZ, Pontianak. He obtained bachelor degree in English Language Education from Univeristas Ahmad Dahlan, Yogyakarta, in 2014. 